\author{
Military Technical College \\ Kobry El-Kobbah, \\ Cairo, Egypt
}

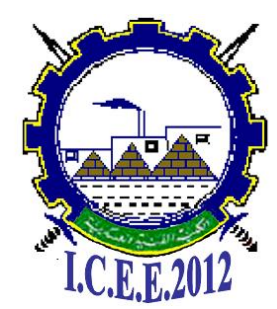

$6^{\text {th }}$ International Conference on

Chemical \& Environmental Engineering

29 -31 May, 2012.

TTEM -2

\title{
MODERN TECHNOLOGYIES OF MANUFACTURING ENERGETIC MATERIALS
}

\author{
Mohamed M.Ismail ${ }^{*}(\mathrm{PhD})$
}

\begin{abstract}
Energetic materials encompass different classes of chemical compostions of fuel and oxidant that react rapidly upon initiation and release large quantites of force or energy. Energetic materials are typically classified as explosives, propellants and pyrotechnics. The technologies of manufacturing energetic materials were extensively improved over the last few decades. Safety, quality and yield were the main burden in any improvements achieved.

In this presentation some of the modern technology of manufacturing energetic materials is presented. A new plant for production of ball grain powder (BGP) will be explained. In this plant the mechanical formation of the BGP using jet stream cutter technology is included which is considered the latest technology in ball poder formation. Also, the modern technology of production of base bleed propallent charge, combustible cartidage case and MTV igniters for large caliber gun ammunitions will be considered. In addition, an advanced continuous process for nitration of cellulose to produce nitrocellulose required for manufacturing of smokless powder will be offered. Moreover, a complete unit for manufacturing homogenous double base propellants is in the scope of this presentation. Furthermore, avery advanced unit for solvent removal and finishing single base propellents is illusterated. Finally, a new plant for production of emulsion explosives is presented. This technology includes sensitization of the emulsion explosive is presented. This technology includes sensitization of the emulsion explosive matrix using either a chemical agent or glass micro-spheres as well as producing both explosive cartridges and bulk emulsion.
\end{abstract}

\footnotetext{
* Vice Chairman of AZ Comp. (Military Factory-18)
} 